\title{
Tourism and ICT. Bibliometric Study on Digital Literacy in Higher Education
}

\author{
David Caldevilla-Domínguez ${ }^{1}$ (D) Alba-María Martínez-Sala ${ }^{2, *(D)}$ and Almudena Barrientos-Báez ${ }^{3}$ (D) \\ 1 Faculty of Information Sciences, Complutense University of Madrid, 28040 Madrid, Spain; \\ davidcaldevilla@ccinf.ucm.es \\ 2 Department of Communication and Social Psychology, University of Alicante, 03690 Alicante, Spain \\ 3 University of La Rioja, 26006 La Rioja, Spain; almudena.barrientosbaez@unir.net \\ * Correspondence: albamaria.martinez@ua.es
}

check for updates

Citation: Caldevilla-Domínguez, D.; Martínez-Sala, A.-M.;

Barrientos-Báez, A. Tourism and ICT. Bibliometric Study on Digital Literacy in Higher Education. Educ. Sci. 2021, 11, 172. https://doi.org/10.3390/ educsci11040172

Academic Editor: Eleanor Dommett

Received: 9 March 2021

Accepted: 1 April 2021

Published: 6 April 2021

Publisher's Note: MDPI stays neutral with regard to jurisdictional claims in published maps and institutional affiliations.

Copyright: (c) 2021 by the authors. Licensee MDPI, Basel, Switzerland. This article is an open access article distributed under the terms and conditions of the Creative Commons Attribution (CC BY) license (https:/ / creativecommons.org/licenses/by/ $4.0 /)$.
Abstract: The scientific production of digital literacy at the university level published in the Scopus database is analyzed, with a special emphasis on studies on tourism due to the relevance of information and communication technology (ICT) in said professional sector. For this, a bibliometric study of a pertinent sample is undertaken using a mixed methodology and based on a series of variables related to formal and content aspects. The last variable, reserved for the academic field under study, directly addresses the main objective as regards tourism. The results show a great global and multidisciplinary interest in digital literacy (DL), mainly from students. There is also a parallel between the integration of ICT into society and the growing evolution of case studies, as well as little interest in their development in specific areas such as tourism studies. Despite good results in general terms, the lack of specialization poses challenges that require greater involvement of training institutions in the sense of providing future professionals with the necessary tools to face them successfully, especially in sectors such as tourism where ICTs are a key piece.

Keywords: bibliometric; digital literacy; digital education; educational technology; higher education; ICT; tourism

\section{Introduction}

Technological development, and especially the 2.0 web model, is causing drastic changes in society in general [1-3]. Information and communication technologies (ICT) have been implemented in the day-to-day life of people, companies, etc., modifying all the processes related to interaction and socialization [4,5], but also other more specific processes, such as those concerning education [6-8]. The educational system needs to adapt to new scenarios resulting from the development and massive implementation of ICT both at a methodological level, adapting the teaching-learning processes, as well as the educational objectives in relation to the training of students $[9,10]$. Hence, there is not only a need to integrate ICTs into training processes, but also to equip students with the knowledge and skills necessary to optimize their use [11-13]. Today there are tools that allow learning processes to be much more personalized and more flexible [14]. In this specific case, ICT training as a cross-cutting element is the key to the correct future professional performance of graduates.

In this sense, at all educational levels and, especially at the university level [15-17], the concept of digital literacy (DL) arises and refers to the safe and critical use of ICT that favors the achievement of objectives. This is not only related to learning, but also to the employability of students and their active participation in society [18-21]. Along the same lines, UNESCO proposes the following definition of DL:

"Digital literacy is the ability to define, access, manage, integrate, communicate, evaluate and create information safely and appropriately through digital technologies and networked devices for participation in economic and social life. It 
includes competencies that are variously referred to as computer literacy, ICT literacy, information literacy, data literacy, and media literacy." [22] (p. 132)

In this sense, in the university academic field, DL implies equipping students with the skills, knowledge, and attitude necessary to interact with digital tools and content in an effective, efficient, and ethical manner, while exploiting all their skills: informative, communicative, relational potential, etc. $[23,24]$. In the current globalized and virtually interconnected business context, the DL of students, as future protagonists of this market, must be incorporated into the university environment as one of the main formative objectives [17]. Its consideration is not only an important curricular innovation [25,26] but it is also an added value for both students and teachers, particularly when it is adapted to different fields of study [17,27-29]. Despite the demands and advantages described, many higher education institutions have not yet fully embraced DL as a fundamental literacy [30].

From the above, it is understood that notable interest exists in academic research on the literacy of university students $[1,19,31]$ characterized by a constant adaptation to the new demands derived from the changes experienced by the social environment, which are caused, to a large extent, by technological development $[10,16,19,32]$. Another feature that defines research on literacy, and specifically on DL, is its focus or specialization in specific areas or disciplines in response to the different levels of demand that professional sectors require of graduates [9,33-35], including the tourist field [36-41].

Higher education plays a key role in acquiring the skills necessary for students to be properly integrated into the professional context [41,42]. In this sense, DL must provide students, in general, with the necessary qualification to face the challenges of the digital information age $[15,43,44]$. This maxim acquires greater relevance among tourism students $[38,40]$ due to the growing impact that ICTs have had on the sector [45-48] and because the forecast, based on the pandemic we are experiencing, is that it will keep growing [49-53].

In the era of digital information, the tourism sector has been one of the sectors that have given the greatest impulse for the introduction of ICT [54], undergoing a profound transformation, as a result of its integration [55,56], with important repercussions for destination management and marketing [57-59]. The technological revolution has affected all agents in the sector, from professionals to consumers, and ICTs have become a key element in the competitiveness of tourism companies $[60,61]$. The challenge for this sector does not lie in accepting the advantages of ICT and integrating them, those that do not do so are doomed to failure, but in doing so in such a way that it is exploited its full potential [62]. For this reason, one of the most important challenges facing this industry is related to ICT training for new generations of tourism professionals [63].

Official studies related to this industry are relatively recent because for a long time it was not considered that the incorporation of this labor into this sector required specific training [64]. This has resulted in an industry in which its workers have been the least qualified academically compared to others [65]. However, in the evolution of tourism towards a crucial sector for the development of many countries [66-68], the specialization and training of its professionals have become a key factor that guarantees the competitiveness of destinations $[63,69]$. This is how, in the face of the professionalization and modernization of a sector in which the demand for qualified personnel is constantly growing, educational institutions have been developing study programs to satisfy this need $[39,69,70]$. In these programs, skills and abilities related to ICT [71-74] are essential given the impact of these tools in the associated professional field $[39,63,75]$. In this regard, the agents that make up the tourism sector question whether the training of graduates of the tourism branch is appropriately adapted to the needs of an increasingly complex and competitive work environment [76] that requires a multitude of skills and competencies [39,63,69,77-79] among which those related to ICTs [63] stand out.

In this sense, research related to education, study programs, etc., of the tourism area is gaining prominence in the academic and professional fields $[69,76,80,81]$ while those 
focused on challenges posed by the integration of ICT in this same industry [60]. Thus, the benefit of delving into those that combine both aspects and focus on the consideration of ICT as a fundamental part of the academic training of tourism students $[40,69]$ and, consequently, on their DL is evident.

Research on education in specific fields and on some of its key aspects, such as DL, is frequent due to the interest in the academic and teaching fields [44,82-84]. Furthermore, technology is a recurring topic due to its implications in the evolution of teaching and the changes that this requires $[1,44,85,86]$. The circumscription to specific disciplines or branches of studies is due to the fact that the aforementioned implications vary among them $[87,88]$. In this sense, and as already indicated, in the field of tourism studies, DL is crucial given the incidence of ICT in this industry [67,89-92].

Based on the above, the main objective of this research consists of analyzing the scientific production on DL in higher education to describe it and, also, determine the degree of prominence of studies on tourism in this field. From the main objective, there are a series of specific objectives that are classified into two sections. The first section brings together those related to the descriptive aspects of the basic characteristics of the documents and that do not require consulting their contents, as is the case of the objectives of the second section.

O1 Formal descriptive objectives:

- O1.1: Determine the evolution of research on DL.

- O1.2: Classify research on DL according to the type of document.

- O1.3: Classify research on DL according to the productivity of the journals.

- O1.4: Classify research on DL according to the productivity of the authors.

O2 Descriptive objectives of the content:

- O2.1: Classification of documents according to their nature.

- O2.2: Classification of documents according to geographic scope.

- O2.3: Classification of documents according to the university population segment of the study.

The set of objectives related to the description and analysis of the literature on DL in higher education is completed with a series of objectives related to the study of DL in the area of tourism.

- O2.4: Classification of documents according to academic/teaching area (in which areas or discipline/s the study is carried out).

- O2.5: Determine the level of presence of research on DL in the field of studies related to the sector and industry of tourism.

To achieve the stated objectives, a systematic literature review is carried out. This is a theoretical construct whose purpose is to review the relevant documents in the field obtained from the most relevant databases $[19,93]$.

\section{Materials and Methods}

The present investigation has been designed following the traditional structure of bibliometric studies in the field of education $[19,44,94,95]$. Therefore, scientific production carried out in a specific area and on a specific topic is analyzed $[8,96]$. Specifically, quantitative and qualitative analysis are combined for the study of DL in higher education, in the field of Social Sciences, Business, Management and Accounting and Economics, and Econometrics and Finance, hereinafter (DLSC), for being the disciplines in which the studies that make up the main object of this research are framed, those related to the tourism sector and industry.

The work was carried out between November 2020 and January 2021, in the Scopus database, one of the most prestigious and credible and essential in the field of bibliometric studies $[8,19,97,98]$. The initial sample $\left(n_{1}=246\right)$ is the result of applying the filters derived from the main objective of this research and which correspond to the words: "Higher education" and "Digital Literacy", both included in the UNESCO thesaurus. The searches 
were carried out in the areas of Social Sciences, Business, Management and Accounting and Economics, Econometrics, and Finance based on the main object of study, tourism education, and in the same way as previous research in the educational field $[83,84]$. Table 1 provides details of the search criteria.

Table 1. Search criteria.

\begin{tabular}{cc}
\hline & Scopus \\
\hline Search field & Article title, Abstract, Keywords \\
Search Words & Higher Education; Digital Literacy \\
Boolean operator & W/0, AND \\
Period & Without delimiting. \\
Subject Area & Social Sciences, Business, Management, and Accounting and \\
Databases & Economics, Econometrics and Finance \\
& Scopus \\
\hline
\end{tabular}

After the initial search, based on the criteria set out in Table 1, the results obtained were reviewed to discard those that did not adhere to the delimited field of study: digital literacy in higher education, obtaining a final sample $\left(n_{2}=220\right)$ which includes all types of publications: articles, books, book chapters, conference publications, etc. The 26 discarded publications were excluded because they do not focus on the analysis or study of digital literacy and/or the field of higher education. Then, following the method used by other authors [19] to guarantee coding reliability, the review and selection of the documents were carried out by the three authors individually, who assessed their suitability on a scale of 1-3. Once evaluated, all those that had obtained a total score equal to or greater than 6 were selected. There were no cases of disagreement, but, if it had occurred, it was planned to be resolved with a fourth reviewer.

Once the final sample was formed, it was studied from the Excel lists provided by the Scopus database and from the documents themselves that were downloaded when the abstract (information that is provided in the database lists) was not sufficient for its classification. The quantitative and qualitative analysis was carried out from a series of macros created in Excel based on the analysis variables resulting from the research objectives set. These are based on previous studies and research as detailed in Table 2, where they are related, at the same time, to the objectives.

Table 2. Study variables.

\begin{tabular}{|c|c|c|c|}
\hline Objective & Analysis Variable & Description & Adapted from \\
\hline \multicolumn{4}{|c|}{ O1 Formal descriptive objectives } \\
\hline O1.1 & Diachronic productivity & Grouping of documents analyzed for years. & {$[1,44,83-86,98]$} \\
\hline $\mathrm{O} 1.2$ & $\begin{array}{l}\text { Productivity by type of } \\
\text { document }\end{array}$ & $\begin{array}{l}\text { Grouping of documents according to the typology } \\
\text { established by Scopus: article, book, book chapter, } \\
\text { conference paper, conference review, and review. }\end{array}$ & {$[44,83,84,97]$} \\
\hline $\mathrm{O} 1.3$ & Magazine productivity & $\begin{array}{l}\text { Grouping of documents according to the journals in } \\
\text { which they have been published. Those who have } \\
\text { published } 2 \text { or more articles about DLSC are shown. }\end{array}$ & {$[1,8,44,83]$} \\
\hline O1.4 & Author productivity & $\begin{array}{l}\text { Documents are grouped by authors. The most } \\
\text { productive are displayed. }\end{array}$ & {$[1,44,83,84,86,98,99]$} \\
\hline \multicolumn{4}{|c|}{ O2 Descriptive objectives of the content } \\
\hline $\mathrm{O} 2.1$ & Productivity by character & $\begin{array}{l}\text { The documents are grouped according to the nature of } \\
\text { the research, distinguishing between experimental and } \\
\text { theoretical. }\end{array}$ & {$[19,31,85,99]$} \\
\hline $\mathrm{O} 2.2$ & $\begin{array}{l}\text { Productivity according to } \\
\text { geographical area }\end{array}$ & $\begin{array}{l}\text { The documents are grouped according to the } \\
\text { geographical scope of the investigation. }\end{array}$ & {$[16,19,99]$} \\
\hline
\end{tabular}


Table 2. Cont.

\begin{tabular}{cccc}
\hline Objective & Analysis Variable & Description & Adapted from \\
\hline O2.3 & $\begin{array}{c}\text { Productivity according to the } \\
\text { population segment under } \\
\text { investigation. }\end{array}$ & $\begin{array}{c}\text { The documents are grouped according to the population } \\
\text { segment in which the degree of DL is evaluated: } \\
\text { teachers, students, etc.; and no, through whom it } \\
\text { is evaluated. }\end{array}$ & $\begin{array}{c}\text { [16,19,99] } \\
\text { O2.4 }\end{array}$ \\
$\begin{array}{c}\text { Productivity according to } \\
\text { academic/teaching area, or } \\
\text { according to discipline }\end{array}$ & $\begin{array}{c}\text { The documents are grouped according to the area/s or } \\
\text { discipline/s in which the research or study is } \\
\text { carried out. }\end{array}$ & [8,16,97] \\
\hline
\end{tabular}

\section{Results}

In this section, we present two types of results based on the two categories of objectives set (O1 and O2). First, the general statistics of sample $\mathrm{n}_{2}$ are discussed to provide an overview of the research on DLSC in higher education. Second, it delves into the nature of the studies and the sample analyzed to reveal the type of research being carried out and the fields of analysis (areas or disciplines) of greatest interest, paying special attention to those related to tourism.

\subsection{Research on DLSC in Higher Education: Formal Description}

First, the diachronic evolution of DLSC research (O1.1) is described. The search has not been temporarily limited, however, the only publication located in 2021 is not included because it is not representative of the productivity of that year since the study covers a single month of that year: January 2021.

Figure 1 shows a general growing trend in research production around the DLSC that stands out particularly in the 2013-2020 period, reaching its maximum in the last three years (2018-2020). Scientific production on DLSC does not emerge until 1997, and no other documents appear until 2006, nine years later. The following years have only one publication per year until 2009, which presents 4. Between 2009 and 2012, production experienced growth and a decrease in the same proportion $(+100 \%)$. This pattern is repeated in the 2013-2016 period with a lower percentage (approximately 30\%). In 2017, production stood at 19, and since then it has not stopped growing, although the most important jump occurs between 2019 and 2020, with a growth of 57\%. The year 2020 had the greatest scientific production on DLSC.

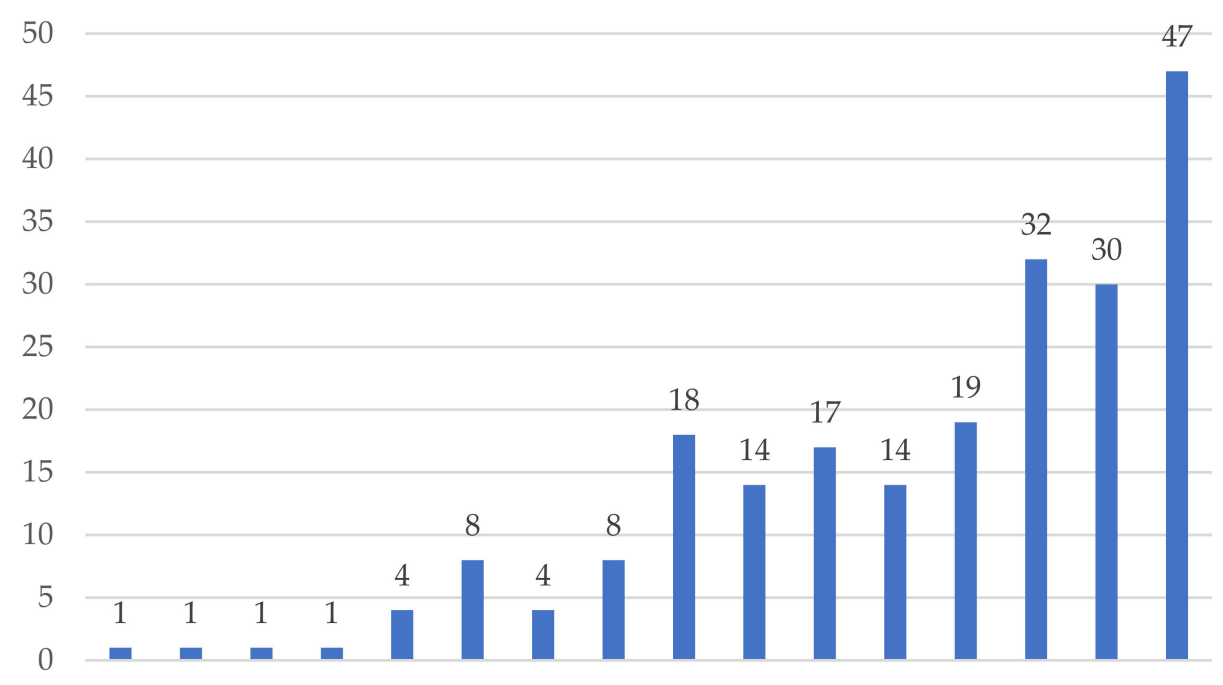

1997200620072008200920102011201220132014201520162017201820192020

Figure 1. Diachronic productivity. 
Below, the productivity according to the type of document established by Scopus is described in Figure 2 (O1.2).

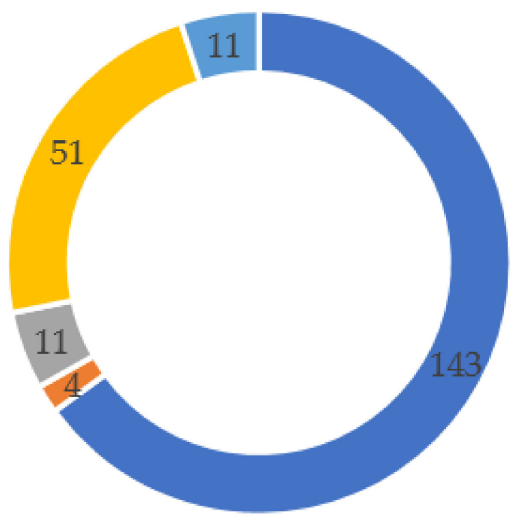

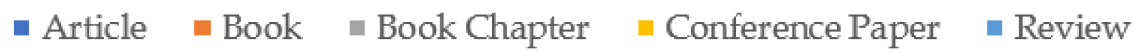

Figure 2. Productivity by type of document.

Of the six types contemplated in Scopus, articles are the most numerous, followed by conference papers. Both account for about $90 \%$ of the total. Regarding the other categories, the sample includes the same number of reviews as the book chapter (11), and there are only 4 books. No conference reviews have been found. The predominance of articles justifies the following evaluation criterion relative to productivity by journals (O1.3). Figure 3 shows all those that have 2 or more articles published on DLSC.

As can be seen in Figure 3, there are two journals that stand out for the number of articles published on DLSC. These journals are Research in Learning Technology and International Journal of Early Childhood Special Education, both with a total of 8 articles. After these, we found a case with 5 published articles (Journal of Information Literacy) and another with 4 (Teaching in Higher Education). The rest are divided into two groups, one of 6 journals with 3 publications, and the majority, which comprises 18 journals, have published 2 articles on the subject. The rest of the magazines, not reflected in the graph, adding up to a total of 141, have published a single article. Table 3 delves into the most relevant journals.

Table 3. Description of journals with more than three articles published on DLSC.

\begin{tabular}{|c|c|c|c|c|c|}
\hline Journal & $\begin{array}{l}\mathrm{N}^{\circ} \text { Articles } \\
\text { about DLSC }\end{array}$ & $\begin{array}{l}\% \text { Total Articles } \\
\text { about DLSC (220) }\end{array}$ & Country & $\begin{array}{c}\text { Impact Index SJR } \\
(2019)\end{array}$ & $\begin{array}{c}\text { Cuartil } \\
\text { Education-SJR } 2019\end{array}$ \\
\hline $\begin{array}{l}\text { Research in } \\
\text { Learning }\end{array}$ & 8 & $3.6 \%$ & United Kingdom & 0.406 & Q2 \\
\hline $\begin{array}{l}\text { Technology } \\
\text { International }\end{array}$ & & & & & \\
\hline $\begin{array}{l}\text { Journal of Early } \\
\text { Childhood Special } \\
\text { Journal of }\end{array}$ & 8 & $3.6 \%$ & Turkey & 0.112 & Q4 \\
\hline $\begin{array}{l}\text { Information } \\
\text { Literacy }\end{array}$ & 5 & $2.3 \%$ & United Kingdom & 0.884 & Q1 \\
\hline $\begin{array}{l}\text { Teaching in Higher } \\
\text { Education }\end{array}$ & 4 & $1.8 \%$ & United Kingdom & 1.284 & Q1 \\
\hline
\end{tabular}




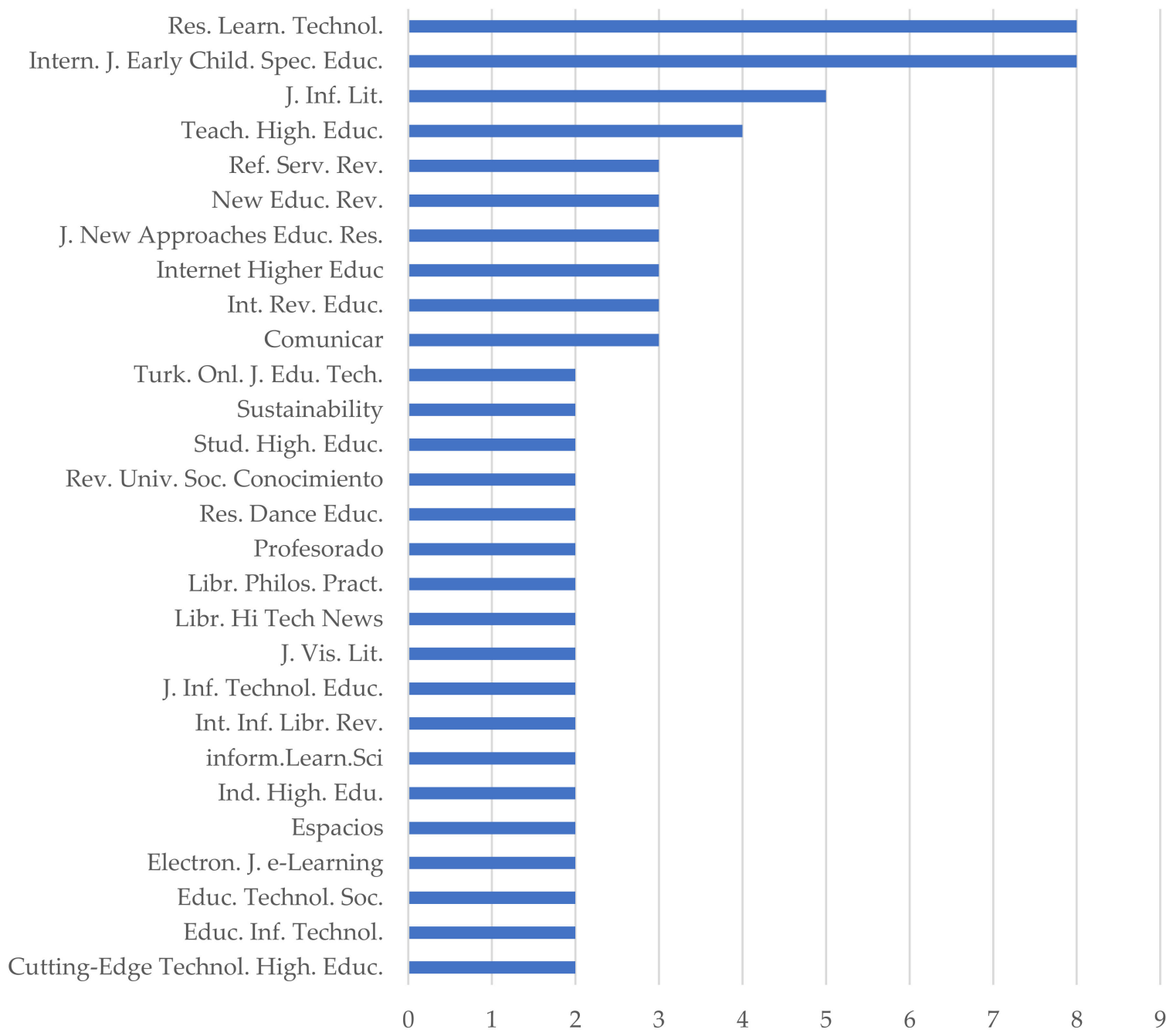

Figure 3. Productivity per journal.

Among the journals with the highest number of articles, those from the United Kingdom and those in the Q1 of education predominate, although the two that occupy this category are the ones that have published the least number of articles (5 and 4) within this group.

Regarding the productivity of the authors, no really remarkable cases have been observed. The 220 documents are signed by a total of 325 authors who are distributed between individual signatures and co-authorship of up to 18 authors, although the most frequent are between 2 and 4 authors. Of the total number of authors, 251 appear in a single document, 34 in two, and only 2 appear in three documents. Precisely these last two, due to their prominence, are the ones described in Table 4.

Table 4. Description of authors with three documents published on DLSC.

\begin{tabular}{|c|c|c|c|c|c|}
\hline Autor & $\begin{array}{c}\mathrm{N}^{\circ} \text { Documents } \\
\text { about DLSC }\end{array}$ & $\begin{array}{c}\% \text { about Total } \\
\text { Documents DLSC } \\
(220)\end{array}$ & $\begin{array}{l}\text { Citations/Documens } \\
\text { by Autor (SJR) }\end{array}$ & H-Index (SJR) & University \\
\hline $\begin{array}{l}\text { Browning, } \\
\text { Francesca }\end{array}$ & 3 & $0.13 \%$ & $1.617 / 80$ & 14 & $\begin{array}{c}\text { Bishop Grosseteste } \\
\text { University, Lincoln, } \\
\text { United Kingdom } \\
\text { Australian } \\
\text { Catholic } \\
\text { University, North } \\
\text { Sydney, NSW, } \\
\text { Australia }\end{array}$ \\
\hline
\end{tabular}


The results shown in Table 4 show two totally opposite cases, apart from the fact that both are women. Browning, F. is an author with little production cataloged in Scopus and, consequently, with an h-Index and number of citations received much lower than the other author, McLoughlin, CE, who has a total of 80 documents in Scopus, 1617 citations, and an h-index of 14 .

\subsection{Research on DLSC in Higher Education: Content Description}

Once the documents were formally described, content analysis was carried for a more in-depth analysis. In this regard, in the first place, O2.1 regarding the nature of the research or study carried out is proposed, and the results are shown in Figure 4.

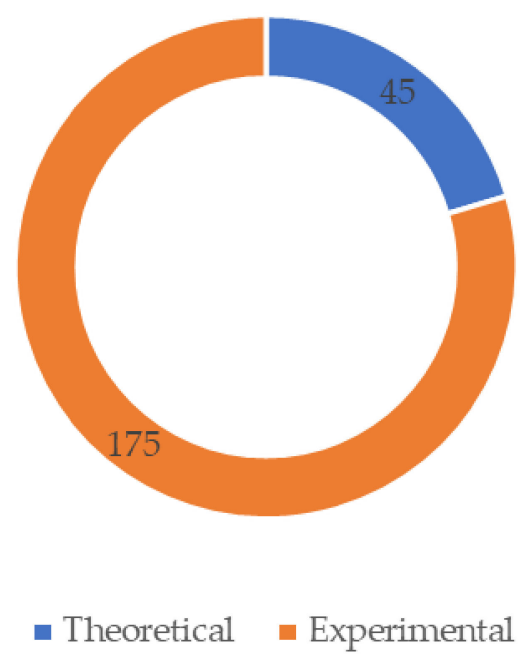

Figure 4. Productivity according to the nature of the research.

The results show a clear predominance of experimental research (empirical research, case studies, etc.). This type represents approximately $80 \%$ of the production, compared to theoretical research (review articles, meta-analysis, etc.). Likewise, it should be noted that the analysis of the abstracts and, when necessary, of the complete documents, has led to considering a greater number of documents as reviews compared to those cataloged by the database. This is considered in the section regarding the nature of the investigation, but not in the one concerning the type of document (Figure 2) where the data reflected have been strictly provided by Scopus.

Once the documents were classified according to the nature of the investigation, they were delimited geographically $(\mathrm{O} 2.2)$. This variable also guides the scope of the studies. Based on the results obtained, four categories have been established: A, for studies that cover one or more continents and more than one country; $\mathrm{B}$, for those that focus on independent countries, principalities, republics, etc.; C, for those developed in states, regions, autonomous communities, etc.; and, finally, D, for the provinces, cities, municipalities, etc.

Figure 5 shows a clear predominance of studies that cover a country (81) followed by those that are carried out in specific localities (64). In the field of reviews, however, those of category A predominate. In relation to the geographic field, the countries, principalities, republics, etc., of an independent nature (category B) where it has been investigated further in DLSC, a total of 56 independent countries, principalities, etc. were counted. Of these, 28 have been the object of study only once, the rest are shown in Figure 6. 


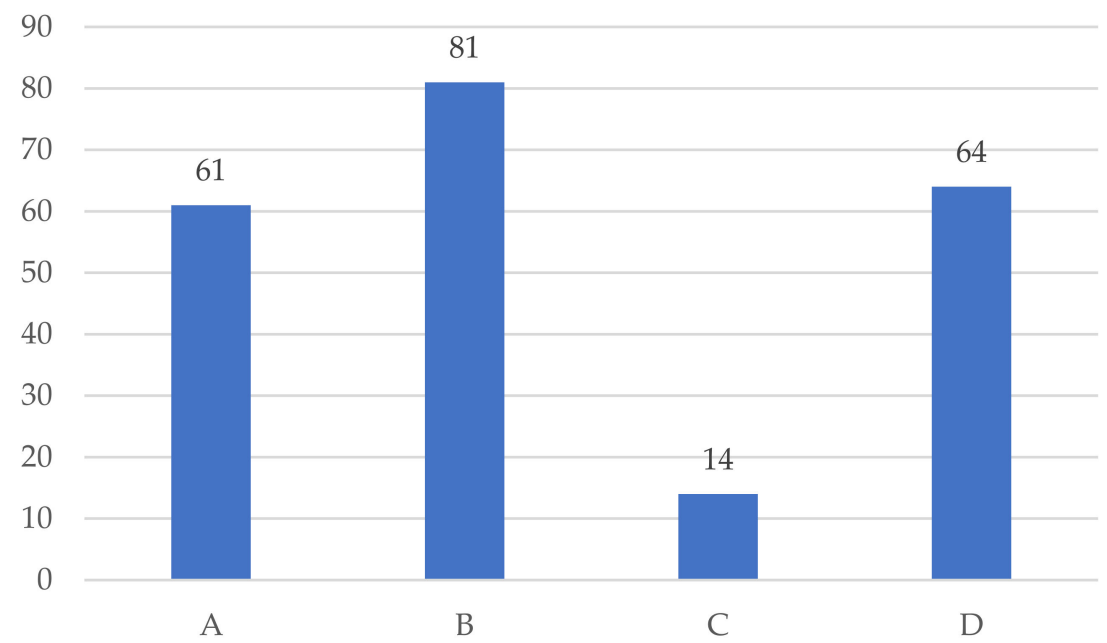

Figure 5. Productivity according to geographical area.

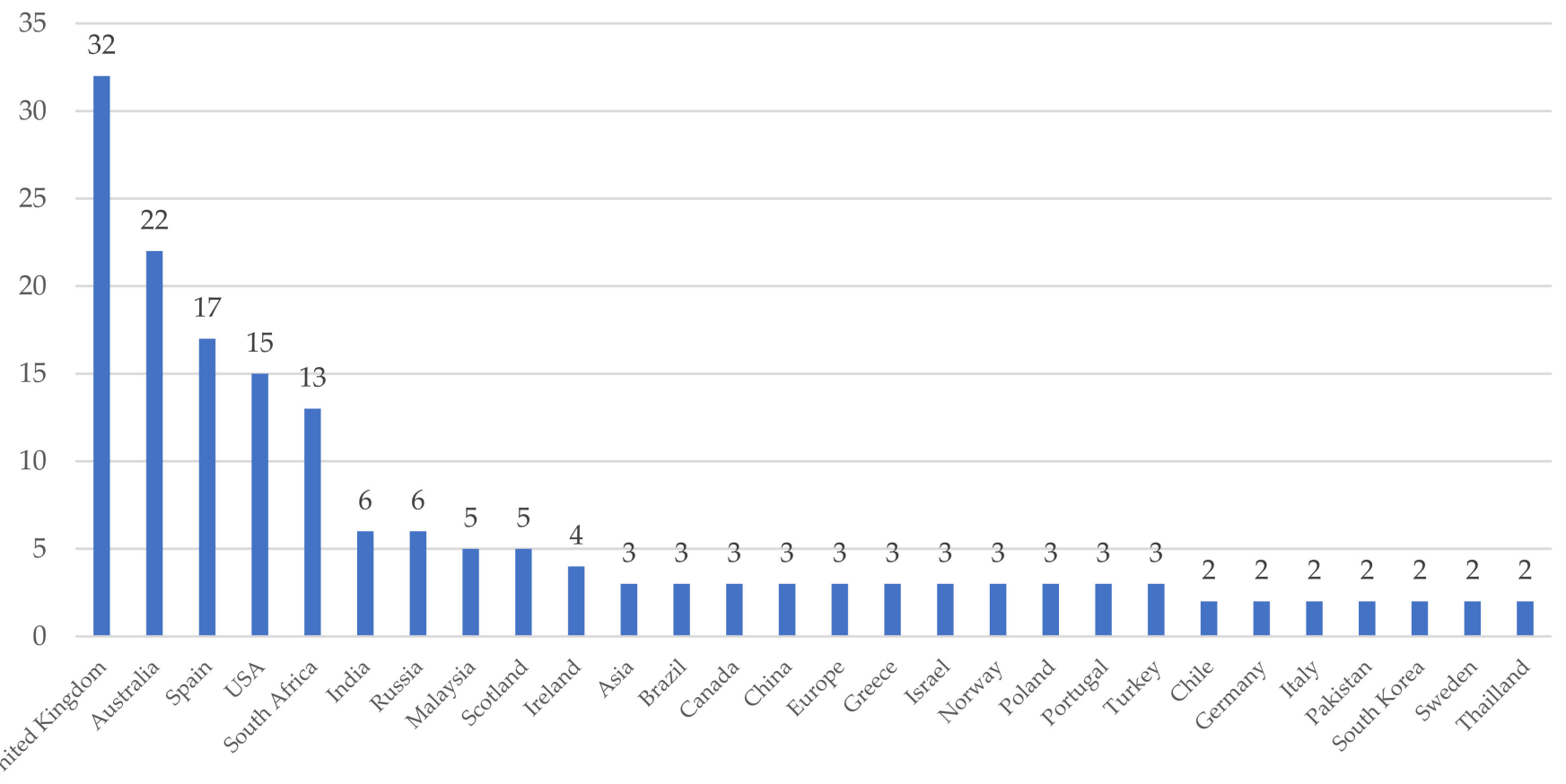

Figure 6. Productivity according to the geographic scope of the research (category B).

The United Kingdom is the country that has been investigated the most concerning DLSC as shown in Figure 6. Followed by Australia and Spain, present in 22 and 17 investigations, respectively. The USA and South Africa also exceed 10 studies, but the bulk is below this figure. Among these, the countries that have been the object of research in 2 and 3 studies stand out. This category includes a total of 18 countries, compared to the 10 that have a presence in more than 4 investigations. Finally, it should be noted that, for the most part, the investigations are focused on a single geographic area, and only 11 are carried out in more than one country.

The next characteristic of the studies that are addressed concerns the population analyzed with its DL (O2.3). This implies differentiating the population between which the research is carried out from that which is the object of study, since, for example, the DL of students can be analyzed by surveying their teachers. The present investigation focuses on the population being studied, and the results reveal that the interest is concentrated on the students (Figure 7). 


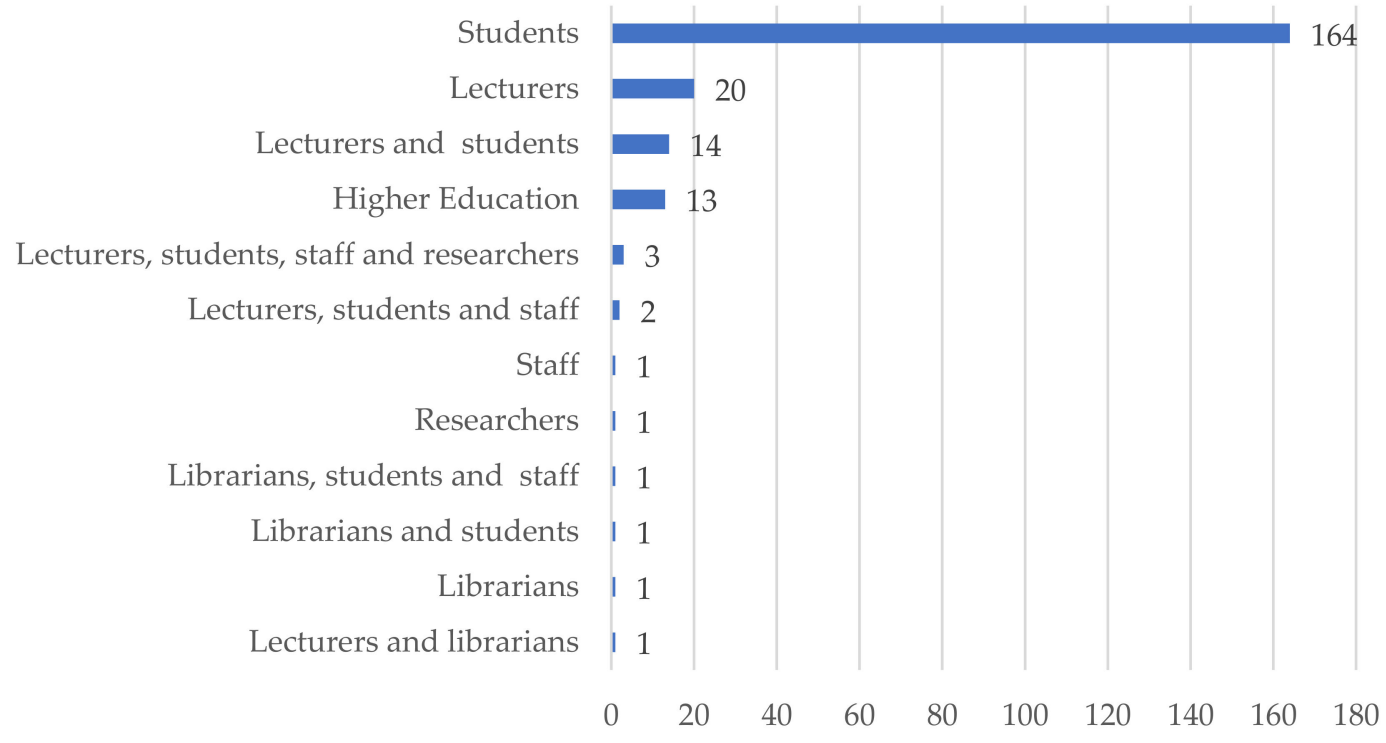

Figure 7. Productivity according to the population segment under investigation.

DL studies account for $84 \%$ of total production (220). As shown in Figure 7, compared to the 164 investigations that focus exclusively on this population segment, there are 7 more that also study other groups (lecturers, staff, librarians, and researchers). The lecturers are the next interest group (approximately 19\%). In this case, as in the case of students, investigations that focus exclusively on them (20) predominate, although they also appear in others in which they are studied together with other groups. The 'Higher Education' category refers to those studies in which no population group is investigated. These are fundamentally reviews about the conceptualization of DL, the evolution of its study, etc.

Finally, the documents are classified according to the academic area or disciplinary area in which they are developed (O2.4). These results, in addition to serving as the description and study of the sample, can address $\mathrm{O} 2.5$ concerning the prominence of studies on tourism in research on DL (Figure 8).

As shown in Figure 8, 17 categories have been established after unifying, at the discipline level, the information provided in the revised documents that varies from one or several specific subjects to one or more disciplines, passing through one or more degrees, postgraduate studies, etc. Many studies do not focus on any specific area but are carried out within the scope of one or more universities. These are reflected in the category 'universities, university' and represent the majority of research on DLSC. Likewise, the 'Higher Education' category is recovered since, as was the case with the population segment variable (Figure 7), they are not associated with any specific discipline.

In relation to the rest of the categories, the 'Education' area stands out as the most researched regarding DL. These represent $37 \%$ of the total production, considering exclusively the documents that are located in a specific academic area. The following disciplines can be grouped into three subcategories. In the first place, we consider those that concern 10 or more documents, where we find areas as disparate as Business and Management, Engineering and Languages, and Philology. It is surprising to see the appearance of the Engineering discipline among the results of a limited search in the areas of Social Sciences, Business, Management and Accounting and Economics, Econometrics, and Finance, but examining the documents reveals that parts of these studies focus on subjects related to the described subject areas, and others appear because Engineering is investigated together with other disciplines of these subject areas. The described group (10-30 documents) adds a total of 38 documents while the last group, which brings together those disciplines that have been considered in less than 10 documents, includes a total of 52 publications. In the last group, a great dispersion is observed and tourism studies are contemplated in only 
2 documents. It is, in both cases, multidisciplinary research that covers areas as diverse as Education, Business, Medicine, and Information Technology.

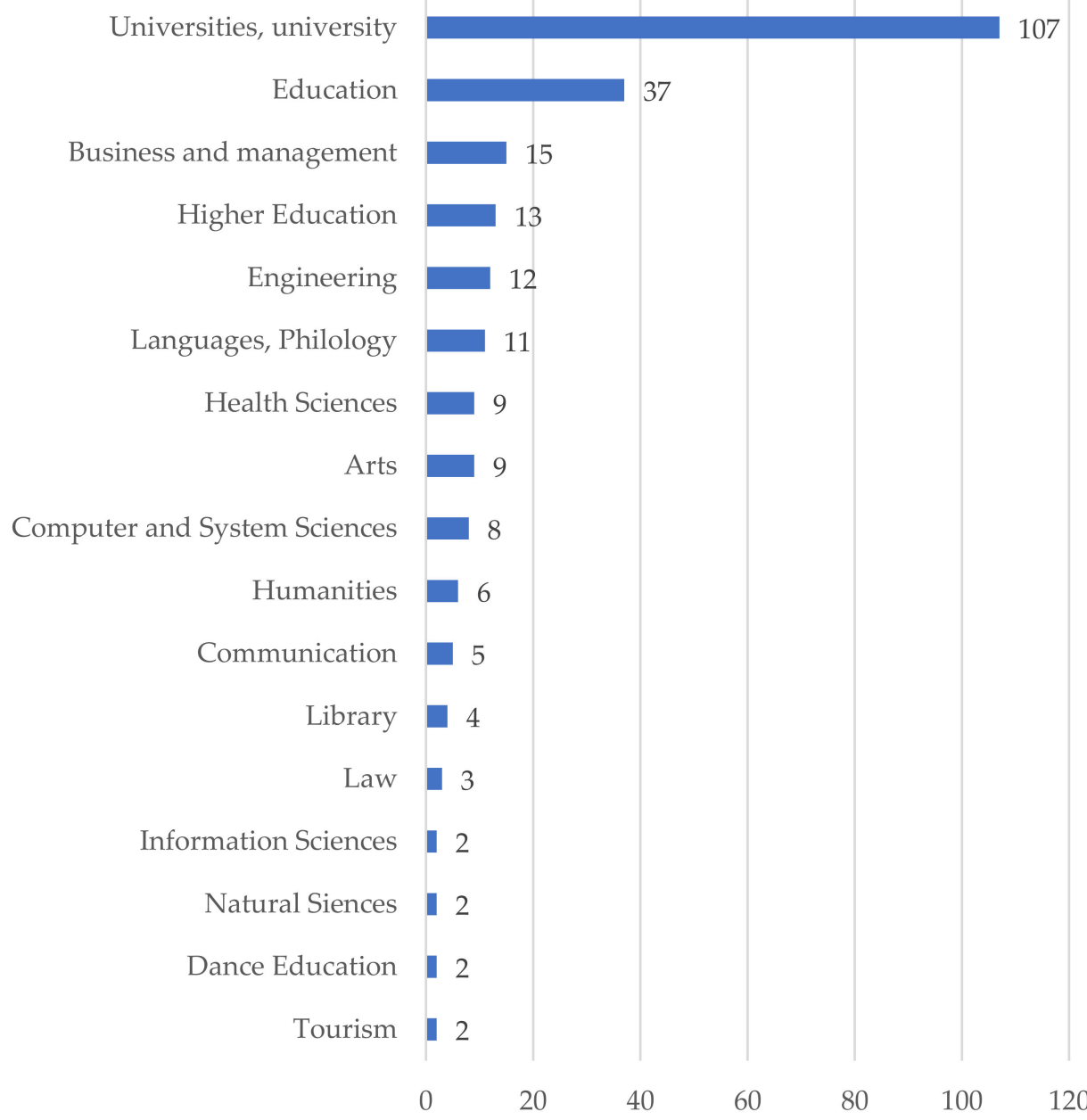

Figure 8. Productivity according to the academic area.

\section{Discussion and Conclusions}

The research carried out contributes to the integration of the DLSC among the objectives of higher education insofar as it analyzes and measures the scientific production in this regard, providing the necessary basis to undertake this type of process successfully $[44,85,98,100]$. Since 1997, the date of the first publication on DLSC in higher education, a total of 220 documents on the subject have been in publications of the Scopus database and considerable growth has been observed since 2017, with 2020 being the year with the highest production. The trend observed is fundamentally due to the growing presence of technology in all areas of society, including education [16,44,101]. Regarding the type of documents, as in other research on the incorporation of technologies and their requirements in the programs and objectives of higher education $[44,83,84,97]$, articles predominate (143) representing $65 \%$ of the total of documents together with the conference papers (51) representing $23 \%$. The results in this area corroborate that researchers focus their efforts on articles because of their impact and credibility within the scientific community [44] and for the accreditation and evaluation of teaching staff. Given the relevance of this type of document, the next objective focuses precisely on the productivity of magazines. In this area, there is a concentration on a few supports, specifically two, as well as a great diversity of magazines that have shown interest in the subject, publishing 1 or more articles. The reality described shows the relevance of the investigated topic and its interdisciplinary nature as it is not limited to specialized journals, even in the case of the two that have stood 
out for the volume of articles since one of them is oriented to Learning Technology while the other focuses on Early Childhood Special Education. Closing the general description of scientific production on DLSC, in relation to the authors and authors, the dispersion observed at the level of the journals is maintained. There are many authors who have been interested in the subject, but few continue in this line of research. This is not an encouraging fact because the constant evolution of ICT requires a constant study and evaluation of their integration in the higher education sphere as teaching-learning tools and also as an educational objective [11-13]. Despite the dispersion observed, the large number of authors and research allows us to foresee that the growing trend that has been observed for several years will continue in the medium-short term. Regarding the most prolific authors, it should be noted that both are women and, with totally opposite profiles as regards the rate of publications and citations in Scopus.

Once this first analysis of the basic characteristics of scientific production on DLSC was carried out, a more in-depth study was carried out in relation to different aspects of its contents. In the first place, the nature of the investigations has been approached, verifying a wide presence of studies of an experimental nature compared to the theoretical ones that, however, predominated in the first years. This evolution reflects that of the integration of ICT in the classroom because more experimental investigations based on case studies have been developed as these tools have been implemented. The observed trend has also been verified in previous research on ICT in higher education $[19,31,85,98]$. Regarding the geographical scope, those that focus on a single area, country, city, etc., stand out. However, within this same category, a great variety and diversity are observed confirming the relevance and impact of the topic investigated worldwide, even though it is also possible to verify a clear predominance of European countries, with the United Kingdom as the maximum exponent.

In this line of research on DLSC, most studies focus on students, and to a lesser extent on teachers, even though their DL is key in order to achieve the ones of the students. Likewise, regarding the population under study, it is found that most studies focus on a single segment while a minority covers more than one group.

Lastly, the documents are classified according to the academic area or discipline being studied. The results indicate a limited specialization since most of the documents are categorized in 'universities, university' as they have not been carried out in any specific area, but in the field of one or several universities. Apart from these, in the group made up of research on a specific area, the one on 'Education' stands out, noting the interest of the academic community regarding the training of future teachers in ICT. As pointed out by Rodríguez-Jiménez et al. [44] higher education is a fundamental stage in the training of future professionals in any field, especially in the case of those who are going to become teachers, because the training of future generations of professionals depends on them. Although the results observed in relation to the studies in the field of 'Education' contrast with the lack of studies on the DL of teachers, previously verified, it also shows the concern and interest of researchers and teachers to guarantee the DL of future teachers.

Finally, regarding the presence of tourism studies, only two documents have been found and, in both cases, they are not exclusively limited to this discipline. This contradicts previous research that found specialization as a characteristic feature of research on literacy, and specifically on DL [9,30-32]. To the results obtained in the SCOPUS database, it is necessary to add other investigations located in other databases that have served to build the theoretical framework and that contrast with the results presented because they focus on tourism, on teachers and are largely signed by the same authors [37-39].

In general terms, it can be concluded that publications on DLSC are approached from different research perspectives, and range from concrete descriptions of teaching-learning methodologies and procedures and how future teachers should use ICT, to more normative approaches $[9,16,43]$ but they are not characterized by specialization and personalization that is crucial at the present time given the degree of professionalization of the current labor market. Organizations, in general terms, must adapt to the new challenges imposed 
by global economic, social, technological, etc. transformations while preserving their competitiveness [61,102]. For this, the development, access, and use of ICTs is not only a key factor but is necessary [103]. In the tourism sector, an industry that has become a source of economic and social development in many territories [61,89], ICTs have generated new opportunities [104] but also the need for more trained professionals in this field who can exploit their full potential to the maximum [63].

The digital information age presents opportunities, but also challenges when it comes to destination marketing and management $[68,105,106]$. These challenges require the involvement of training institutions in the sense of providing future professionals with the necessary tools to face them $[40,41,69]$ because human resources are crucial to achieving a real advantage in the global tourism industry, characterized by its volatility and competitiveness [107]. The results obtained represent a contribution to the academic and professional fields since scientific activity is evaluated with respect to DLSC in higher education, providing crucial information to tackle the challenges described $[44,85,98,100]$. Higher education and ICT must form an indissoluble pairing that serves as a model for the previous educational stages, becoming a source of theoretical and practical knowledge about $\mathrm{DL}$, about how to turn students into expert professionals in the creation, development, and use of ICT. This is the goal pursued by this study and which has been materialized in a photograph of the evolution and current state of the scientific literature on DLSC, with special attention to studies on tourism. The meager results obtained in this regard contrast with the relevance of ICT in the corresponding sector, conferring added value to the line of research initiated in terms of its projection, since for tourism students the integration of ICT in their face training is crucial upon their incorporation into the professional field [40] and this process will not be successful unless their DL is previously undertaken.

Despite the achievement of the goal and objectives, the research carried out is not exempt from limitations that are established as next phases or future lines. These are mainly related to the sample that should be expanded to other relevant databases such as Web of Science (WOS) as well as to other teaching areas and disciplines, giving it a global approach and a new perspective that addresses the universal and global nature of the DL.

Author Contributions: Conceptualization, methodology, validation, formal analysis, investigation, resources, data curation, writing-original draft preparation, D.C.-D. and A.-M.M.-S.; writingreview and editing, visualization and supervision, D.C.-D., A.-M.M.-S. and A.B.-B. All authors have read and agreed to the published version of the manuscript.

Funding: This research received no external funding.

Institutional Review Board Statement: Not applicable.

Informed Consent Statement: Not applicable.

Data Availability Statement: Data sharing not applicable.

Acknowledgments: This work has been completed thanks to the collaboration of the research groups on Experiential Marketing, Events and Integrated Communication (MAE-CO) of the University of Alicante, and the research group on Strategic Communication Management (GCE) of the Private University of La Loja.

Conflicts of Interest: The authors declare no conflict of interest.

\section{References}

1. Hinojo-Lucena, F.J.; Aznar-Díaz, I.; Cáceres-Reche, M.P.; Romero-Rodríguez, J.M. Artificial intelligence in higher education: A bibliometric study on its impact in the scientific literature. Educ. Sci. 2019, 9, 51. [CrossRef]

2. Darwish, A.; Lakhtaria, K.I. The Impact of the New Web 2.0 Technologies in Communication, Development, and Revolutions of Societies. J. Adv. Inf. Technol. 2011, 2, 204-216. [CrossRef]

3. O'Reilly, T. What is the Web 2.0. Design Patterns and Business Models for the Next Generation of Software. Available online: https://www.oreilly.com/pub/a/web2/archive/what-is-web-20.html (accessed on 9 March 2021).

4. Morimoto, S.A.; Friedland, L.A. The lifeworld of youth in the information society. Youth Soc. 2011, 43, 549-567. [CrossRef]

5. León, M.E.L.; Medina, H.S. Las TIC. Un nuevo escenario para el desarrollo local de las comunidades. Opcion $2016,32,71-94$. 
6. Dornaleteche, J.; Buitrago, A.; Moreno, L. Categorization, item selection and implementation of an online digital literacy test as media literacy indicator. Comunicar 2015, 22, 177-185. [CrossRef]

7. Tur, G.; Urbina, S. La colaboración en eportafolios con herramientas de la Web 2.0 en la formación docente inicial. Cult. Educ. 2016, 28, 601-632. [CrossRef]

8. Stopar, K.; Bartol, T. Digital competences, computer skills and information literacy in secondary education: Mapping and visualization of trends and concepts. Scientometrics 2019, 118, 479-498. [CrossRef]

9. Peña-Acuña, B.; Martínez-Sala, A.-M.; Felipe Morales, A. Flexibilidad en Apps de cuentos de realidad aumentada. Utopía Prax. Latinoam. 2020, 25, 225-243. [CrossRef]

10. Ocaña-Fernández, Y.; Fernández, L.A.V.; Chiparra, W.E.M.; Gallarday-Morales, S. Digital skills and digital literacy: New trends in vocational training. Int. J. Early Child. Spec. Educ. 2020, 12, 370-377. [CrossRef]

11. Martínez-Sala, A.-M.; Alemany-Martínez, D. Integración eficiente de redes sociales como herramientas complementarias de aprendizaje y para la alfabetización digital en los estudios superiores de Publicidad y RR. PP. In El Compromiso Académico y Social a Través de la Investigación e Innovación Educativas en la Enseñanza Superior; Roig-Vila, R., Ed.; Ediciones Octaedro: Barcelona, Spain, 2018; pp. 1126-1136, ISBN 978-84-17219-25-3.

12. McMahon, M. Ensuring the development of Digital Literacy in higher education curricula. In Proceedings of the Annual Conference of the Australasian Society for Computers in Learning in Tertiary Education, Dunedin, New Zealand, 23-26 November 2014; pp. 524-528.

13. Domingo-Coscollola, M.; Bosco-Paniagua, A.; Carrasco-Segovia, S.; Sánchez-Valero, J.-A. Fomentando la competencia digital docente en la universidad: Percepción de estudiantes y docentes. Rev. Investig. Educ. 2019, 38, 167-182. [CrossRef]

14. Barrientos-Báez, A. GDS Amadeus. Propuesta de innovación didáctica. In TIC Actualizadas para una nueva Docencia Universitaria; Durán Medina, J.V., Durán Valero, I., Eds.; McGraw-Hill: New York, NY, USA, 2016; pp. 17-30, ISBN 9788448612658.

15. Odede, I.; Jiyane, G. Exploring dimensional constructs of digital literacy skills for higher education. Libr. Philos. Pract. 2019, 2019, 2806.

16. Spante, M.; Hashemi, S.S.; Lundin, M.; Algers, A. Digital competence and digital literacy in higher education research: Systematic review of concept use. Cogent Educ. 2018, 5, 1-21. [CrossRef]

17. Katzlinger, E.; Niederländer, U. Supporting virtual learning for digital literacy: First experiences with a mobile app and gamification elements. Proc. Eur. Conf. e-Learn. 2018, 2018, 235-244.

18. Peled, Y. Pre-service teacher's self-perception of digital literacy: The case of Israel. Educ. Inf. Technol. 2020. [CrossRef] [PubMed]

19. Sánchez-Caballé, A.; Gisbert-Cervera, M.; Esteve-Mon, F. The digital competence of university students: A systematic literature review. Aloma 2020, 38, 63-74. [CrossRef]

20. Almansa-Martinez, A.; Van-Zummeren Moreno, G.; Haro, R. Functionalities of Moodle and Edmodo in the Middle and Higher Educations. Rev. Comun. SEECI 2019, 50, 87-105. [CrossRef]

21. Salas-Rueda, R.-A.; Salas-Rueda, R.-D. Análisis Sobre El Uso De La Red Social Facebook En El Proceso De Enseñanza-Aprendizaje Por Medio De La Ciencia De Datos Tt_Analysis on the Use of the Social Network Facebook in the Teaching-Learning Process Through Data Science Analises Sobre O Uso Da. Rev. Comun. SEECI 2020, 1, 1-26.

22. Law, N.; Woo, D.; de la Torre, J.; Wong, G. A Global Framework of Reference on Digital Literacy Skills for Indicator 4.4.2.; UNESCO: Paris, France, 2018.

23. Julien, H. Digital literacy in theory and practice. In Encyclopedia of Information Science and Technology; Khosrow-Pour, M., Ed.; IGI Global: Hershey, PA, USA, 2018; pp. 22-32.

24. Neumann, M.M.; Finger, G.; Neumann, D.L. A conceptual framework for emergent digital literacy. Early Child. Educ. J. 2017, 45, 471-479. [CrossRef]

25. Holt, D.; Smissen, I.; Segrave, S. New students, new learning, new environments in higher education: Literacies in the digital age. In Proceedings of the 23rd Annual Ascilite Conference of the Australasian Society for Computers in Learning in Tertiary Education: Who's Learning? Whose Technology? Sydney, Australia, 3-6 December 2006; pp. 327-337.

26. Pugacheva, N.; Kirillova, T.; Kirillova, O.; Luchinina, A.; Korolyuk, I.; Lunev, A. Digital paradigm in educational management: The case of construction education based on emerging technologies. Int. J. Emerg. Technol. Learn. 2020, 15, 96-115. [CrossRef]

27. English, J.A. A Digital Literacy Initiative in Honors: Perceptions of Students and Instructors about its Impact on Learning and Pedagogy. J. Natl. Coll. Honor. Counc. 2016, 17, 125-155.

28. Starčič, A.I.; Cotic, M.; Solomonides, I.; Volk, M. Engaging preservice primary and preprimary school teachers in digital storytelling for the teaching and learning of mathematics. Br. J. Educ. Technol. 2016, 47, 29-50. [CrossRef]

29. Varga-Atkins, T. Beyond description: In search of disciplinary digital capabilities through signature pedagogies. Res. Learn. Technol. 2020, 28, 1-19. [CrossRef]

30. Murray, M.C.; Pérez, J. Unraveling the Digital Literacy Paradox: How Higher Education Fails at the Fourth Literacy. Issues Informing Sci. Inf. Technol. 2014, 11, 85-100. [CrossRef]

31. Recio Muñoz, F.; Silva Quiroz, J.; Abricot Marchant, N. Análisis de la Competencia Digital en la Formación Inicial de estudiantes universitarios: Un estudio de meta-análisis en la Web of Science. Píxel-BIT Rev. Medios Educ. 2020, 125-146. [CrossRef]

32. Oliveira, C.; Lopes, J.; Spear-Swerling, L. Teachers' academic training for literacy instruction. Eur. J. Teach. Educ. 2019, 42, 315-334. [CrossRef]

33. You, Y. Online technologies in dance education (China and worldwide experience). Res. Danc. Educ. 2020. [CrossRef] 
34. Hunma, A. Students make history every day just by sitting on these steps: Performative spaces and re-genring in the south. Educ. Chang. 2018, 22, 1-25. [CrossRef]

35. Shopova, T. Digital literacy of students and its improvement at the university. J. Effic. Responsib. Educ. Sci. 2014, 7, 26-32. [CrossRef]

36. Phuapan, P.; Viriyavejakul, C.; Pimdee, P. An analysis of Digital Literacy Skills among Thai University Seniors. Int. J. Emerg. Technol. Learn. 2016, 11, 24-31. [CrossRef]

37. Avello, R.; López, R.; Gómez, M.; Espinosa, G.; Vázquez, S. Necesidades de formación en TIC de los docentes de las escuelas de Hotelería y Turismo cubanas. IJERI Int. J. Educ. Res. Innov. 2014, 1, 15-28.

38. Avello-Martínez, R.; López-Fernández, R.; Alpizar-Fernández, R. Sistema de formación continua para la alfabetización digital de los docentes de la escuela de hotelería y turismo de Cienfuegos. Rev. Educ. Distancia 2016. [CrossRef]

39. Avello-Martínez, R.; López Fernández, R. Digital literacy for teachers in Cuban Tourism and Hotel Management Schools. Some experiences on its development. RUSC. Univ. Knowl. Soc. J. 2015, 12, 3. [CrossRef]

40. Cowie, B.; Khoo, E. Digital tools disrupting tertiary students' notions of disciplinary knowledge: Cases in history and tourism. Educ. Sci. 2014, 4, 87-107. [CrossRef]

41. Infante-Moro, A.; Infante-Moro, J.; Gallardo-Pérez, J. The acquisition of ICT skills at the university level: The case of the Faculty of Business Studies and Tourism of the University of Huelva. Pixel-Bit Rev. Medios Educ. 2021, 29-58. [CrossRef]

42. Pérez-Mateo, M.; Romero, M.; Romeu-Fontanillas, T. Collaborative construction of a project as a methodology for acquiring digital competences. Comunicar 2014, 21, 15-23. [CrossRef]

43. Lea, M.R. Reclaiming literacies: Competing textual practices in a digital higher education. Teach. High. Educ. 2013, 18, 106-118. [CrossRef]

44. Rodríguez Jiménez, C.; Sanz Prieto, M.; Alonso García, S. Technology and higher education: A bibliometric analysis. Educ. Sci. 2019, 9, 169. [CrossRef]

45. Huertas, A.; Marine-Roig, E. Differential destination content communication strategies through multiple Social Media. In Information and Communication Technologies in Tourism 2016; Inversini, A., Schegg, R., Eds.; Springer: Cham, Switzerland, 2016; pp. 239-252.

46. Ivars-Baidal, J.A.; Celdrán-Bernabeu, M.A.; Mazón, J.-N.; Perles-Ivars, Á.F. Smart destinations and the evolution of ICTs: A new scenario for destination management? Curr. Issues Tour. 2019, 22, 1581-1600. [CrossRef]

47. Petrović, J.; Milićević, S.; Djeri, L. The information and communications technology as a factor of destination competitiveness in transition countries in European Union. Tour. Econ. 2016, 23, 1353-1361. [CrossRef]

48. Marine-Roig, E.; Huertas, A. How safety affects destination image projected through online travel reviews. J. Destin. Mark. Manag. 2020, 18, 100469. [CrossRef]

49. Martínez-Sala, A.-M. ¡Hay turismo después del COVID-19!: Una crisis para la reflexión y el cambio. Desarro. Econ. Soc. 2020, 9 , 43-53. [CrossRef]

50. Williams, C.C. Impacts of the coronavirus pandemic on Europe's tourism industry: Addressing tourism enterprises and workers in the undeclared economy. Int. J. Tour. Res. 2020, 1-10. [CrossRef]

51. Huertas, A.; Oliveira, A.; Girotto, M. Crisis communication management by the national tourist organizations of spain and italy in the face of COVID-19. Prof. Inf. 2020, 1-19. [CrossRef]

52. Villa, F.G.; Litago, J.D.U.; Sánchez-Fdez, A. Perceptions and expectations in the university students from adaptation to the virtual teaching triggered by the covid-19 pandemic. Rev. Lat. Comun. Soc. 2020, 2020, 99-119. [CrossRef]

53. Tejedor, S.; Cervi, L.; Tusa, F.; Parola, A. Education in times of pandemic: Reflections of students and teachers on virtual university education in Spain, Italy and Ecuador. Rev. Lat. Comun. Soc. 2020, 2020, 1-21. [CrossRef]

54. Gössling, S. Tourism, technology and ICT: A critical review of affordances and concessions. J. Sustain. Tour. 2021. [CrossRef]

55. Zaidan, E. Analysis of ICT usage patterns, benefits and barriers in tourism SMEs in the Middle Eastern countries: The case of Dubai in UAE. J. Vacat. Mark. 2016, 23, 248-263. [CrossRef]

56. Ukpabi, D.C.; Karjaluoto, H. Consumers' acceptance of information and communications technology in tourism: A review. Telemat. Inform. 2017, 34, 618-644. [CrossRef]

57. Gössling, S. Tourism, information technologies and sustainability: An exploratory review. J. Sustain. Tour. 2017, 25, 1024-1041. [CrossRef]

58. Fernández Paradas, R.; Sánchez Guzmán, R. La revolución Youtube y su influencia en la construcción de las identidades locales por medio de la Semana Santa. Rev. Cienc. Comun. Inf. 2018, 23, 53-66. [CrossRef]

59. Walls Ramírez, M. Aportes de la comunicación para la difusión del patrimonio cultural. Rev. Cienc. Comun. Inf. 2020, 25, 49-55. [CrossRef]

60. Gjika, I.; Pano, N. Effects of ICT in Albanian tourism business. Acad. J. Interdiscip. Stud. 2020, 9, 252-263. [CrossRef]

61. Milićević, S.; Petrović, J.; Dordević, N. ICT as a factor of destination competitiveness: The case of the republics of former Yugoslavia. Manag. Mark. 2020, 15, 381-392. [CrossRef]

62. Porter, M. Strategy and the Internet. Harv. Bus. Rev. 2001, 3, 2-19.

63. Bilotta, E.; Bertacchini, F.; Gabriele, L.; Giglio, S.; Pantano, P.S.; Romita, T. Industry 4.0 technologies in tourism education: Nurturing students to think with technology. J. Hosp. Leis. Sport Tour. Educ. 2020. [CrossRef] 
64. Cooper, C.; Shepherd, R. The Relationship Between Tourism Education and The Tourism Industry: Implications for Tourism Education. Tour. Recreat. Res. 1997, 22, 34-47. [CrossRef]

65. Baum, T. Human resources in tourism: Still waiting for change. Tour. Manag. 2007, 28, 1383-1399. [CrossRef]

66. Buhalis, D.; Amaranggana, A. Smart Tourism Destinations Enhancing Tourism Experience Through Personalisation of Services BTInformation and Communication Technologies in Tourism 2015; Tussyadiah, I., Inversini, A., Eds.; Springer: Cham, Switzerland, 2015; pp. 377-389.

67. Gretzel, U.; Sigala, M.; Xiang, Z.; Koo, C. Smart tourism: Foundations and developments. Electron. Mark. 2015, 25, 179-188. [CrossRef]

68. Gretzel, U.; Yuan, Y.-L.; Fesenmaier, D.R. Preparing for the New Economy: Advertising Strategies and Change in Destination Marketing Organizations. J. Travel Res. 2000, 39, 146-156. [CrossRef]

69. Balbuena, A.; Salinas, D.S.; Suasnavas, M.G. Explorando la posibilidad de implementar un posgrado de turismo en Loja (Ecuador). Rev. Espac. 2019, 40, 2017-2021.

70. Abdul-Ghani, M. Hospitality and Tourism Education in the Making. J. Teach. Travel Tour. 2006, 6, 71-87. [CrossRef]

71. Agüero Pérez, M.M.; López Fraile, L.A.; Pérez Expósito, J. Challenge Based Learning como modelo de aprendizaje profesionalizante. Caso del programa Universidad Europea con Comunica +A. Vivat Acad. 2019, 149, 1-24. [CrossRef]

72. Sabich, M. De los libros de texto a los portales educativos: Un análisis sociosemiótico sobre sus estrategias discursivas. El caso de Introducción a la Comunicación y Educar. Perspect. Comun. 2015, 8, 59-93.

73. Cuéllar Santiago, F.; López-Aparicio Pérez, I. Vieo Art as a methodological tool and creative catalyst. The acquisition of competences in Media Literacy with the help of emotions. Vivat Acad. 2020, 151, 127-156. [CrossRef]

74. Gordillo, A. Comunicación y Educación en contextos mediados: Nuevos desafíos para la construcción y difusión del conocimiento. Perspect. Comun. 2015, 8, 7-23.

75. García-Marín, D. Transpodcast universe. Narrative models and independent community. Hist. Comun. Soc. 2020, 25, 139-149. [CrossRef]

76. Assante, L.M.; Huffman, L.; Harp, S.S. A Taxonomy of Academic Quality Indicators for U.S.-Based 4-Year Undergraduate Hospitality Management Programs. J. Hosp. Tour. Res. 2009, 34, 164-184. [CrossRef]

77. Durán Medina, J.F.; Vega Baeza, M.R. Las tecnologías de la información y de la comunicación en las facultades de educación. Ilu 2013, 18, 313-326. [CrossRef]

78. Arroyo-Vázquez, N.; Gómez-Hernández, J.-A. La biblioteca integrada en la enseñanza universitaria online: Situación en España. Prof. Inf. 2020, 1-11. [CrossRef]

79. Calvo-Rubio, L.-M.; Ufarte-Ruiz, M.-J. Percepción de docentes universitarios, estudiantes, responsables de innovación y periodistas sobre el uso de inteligencia artificial en periodismo. Prof. Inf. 2020, 29, 1-14. [CrossRef]

80. Gursoy, D.; Swanger, N. An Industry-Driven Model of Hospitality Curriculum for Programs Housed in Accredited Colleges of Business. J. Hosp. Tour. Educ. 2004, 16, 13-20. [CrossRef]

81. Gursoy, D.; Swanger, N. An Industry-Driven Model of Hospitality Curriculum for Programs Housed in Accredited Colleges of Business: Part II. J. Hosp. Tour. Educ. 2005, 17, 46-56. [CrossRef]

82. Akçayır, M.; Akçayır, G. Advantages and challenges associated with augmented reality for education: A systematic review of the literature. Educ. Res. Rev. 2017, 20,1-11. [CrossRef]

83. Repiso, R.; Fonseca-Mora, M.C. Aproximación Bibliométrica del Desarrollo e Impacto de la Investigación Internacional en Alfabetización Audiovisual (1960-2011). Rev. Cient. Comun. Tecnol. Emerg. 2012, 10, 43-61. [CrossRef]

84. Lorenzo Lledó, G.; Scagliarini Galiano, C. Revisión bibliométrica sobre la realidad aumentada en Educación. Rev. Gen. Inf. y Doc. 2018, 28, 45-60. [CrossRef]

85. Fernández Batanero, J.M.; Reyes Rebollo, M.M.; Montenegro Rueda, M. Impact of ICT on students with high abilities. Bibliographic review (2008-2018). Comput. Educ. 2019, 137, 48-58. [CrossRef]

86. Bond, M.; Zawacki-Richter, O.; Nichols, M. Revisiting five decades of educational technology research: A content and authorship analysis of the British Journal of Educational Technology. Br. J. Educ. Technol. 2019, 50, 12-63. [CrossRef]

87. Bhatt, I.; MacKenzie, A. Just Google it! Digital literacy and the epistemology of ignorance. Teach. High. Educ. 2019, 24, 302-317. [CrossRef]

88. Elphick, M. The impact of embedded ipad use on student perceptions of their digital capabilities. Educ. Sci. 2018, 8, 102. [CrossRef]

89. Martínez-Sala, A.-M.; Cifuentes Albeza, R.; Martínez-Cano, F.J. Las redes sociales de las organizaciones de marketing de destinos turísticos como posible fuente de eWOM. Observatorio 2018, 12, 246-271. [CrossRef]

90. López, E.P.; Barrientos, A.; Martínez, J.A. La transformación digital del turismo. Rev. Occident. 2020, 464, 52-66.

91. Lerario, A.; Varasano, A.; Di Turi, S.; Maiellaro, N. Smart Tirana. Sustainability 2017, 9, 2338. [CrossRef]

92. Li, Y.; Hu, C.; Huang, C.; Duan, L. The concept of smart tourism in the context of tourism information services. Tour. Manag. 2017, 58, 293-300. [CrossRef]

93. Vangrieken, K.; Dochy, F.; Raes, E.; Kyndt, E. Teacher collaboration: A systematic review. Educ. Res. Rev. 2015, 15, 17-40. [CrossRef]

94. Fernández-Cano, A.; Bueno, A. Synthesizing scientometric patterns in Spanish educational research. Scientometrics 1999, 46, 349-367. [CrossRef] 
95. Villalba Trujillo, R.; Martínez Caro, L.; Martínez María-Dolores, S.-M. Regional analysis of tourism companies online in Spain. Cuad. Tur. 2014, 34, 335-349.

96. Diem, A.; Wolter, S.C. The Use of Bibliometrics to Measure Research Performance in Education Sciences. Res. High. Educ. 2013, 54, 86-114. [CrossRef]

97. Tibaná-Herrera, G.; Fernández-Bajón, M.T.; De Moya-Anegón, F. Categorization of an emerging discipline in the world publication system (SCOPUS): E-learning. arXiv 2017, arXiv:1710.05723.

98. González-Zamar, M.D.; Abad-Segura, E. Implications of virtual reality in arts education: Research analysis in the context of higher education. Educ. Sci. 2020, 10, 225. [CrossRef]

99. O'Connor, S.; Daly, C.S.; MacArthur, J.; Borglin, G.; Booth, R.G. Podcasting in nursing and midwifery education: An integrative review. Nurse Educ. Pract. 2020, 47, 102827. [CrossRef]

100. Mayes, R.; Natividad, G.; Spector, J.M. Challenges for educational technologists in the 21st century. Educ. Sci. 2015, 5, 221-237. [CrossRef]

101. Almenara, J.C.; Vázquez-Cano, E.; Meneses, E.L.; Martínez, A.J. Formative possibilities of augmented technology. A diachronic study in University Scenarios. Rev. Complut. Educ. 2020, 31, 141-152. [CrossRef]

102. Drăgoi, M.C.; Andrei, J.V.; Mieilă, M.; Panait, M.; Dobrotă, C.E.; Lădaru, R.G. Food safety and security in Romania-an econometric analysis in the context of national agricultural paradigm transformation. Amfiteatru Econ. 2018, 20, 134-151. [CrossRef]

103. Bejtkovský, J.; Copca, N. The Employer Branding Creation and HR Marketing in Selected Healthcare Service Providers. Manag. Mark. 2020, 15, 95-108. [CrossRef]

104. Manente, M.; Minghetti, V. Destination management organizations and actors. In Tourism Business Frontiers. Consumers, Products and Industry; Buhalis, D., Costa, C., Eds.; Elsevier Butterworth-Heinemann: Oxford, UK, 2006; pp. $228-237$.

105. Pike, S.; Page, S.J. Destination Marketing Organizations and destination marketing: Anarrative analysis of the literature. Tour. Manag. 2014, 41, 202-227. [CrossRef]

106. Minghetti, V.; Buhalis, D. Digital Divide in Tourism. J. Travel Res. 2009, 49, 267-281. [CrossRef]

107. Mayaka, M.; Akama, J.S. Systems approach to tourism training and education: The Kenyan case study. Tour. Manag. 2007, 28, 298-306. [CrossRef] 